\title{
Colonization patterns of reef fish larvae to the lagoon at Moorea Island, French Polynesia
}

\author{
Vincent Dufour, René Galzin \\ Laboratoire d'Ichtyoécologie Tropicale et Méditerranéenne, Ecole pratique des Hautes Etudes, URA CNRS 1453, Université \\ de Perpignan, F-66860 Perpignan Cedex, France \\ and \\ Antenne EPHE, Centre de l'Environnement, BP 1013 Moorea, French Polynesia
}

\begin{abstract}
Colonization of the lagoon at Moorea Island, French Polynesia, by fish larvae was studied with a net fixed on the outer reef crest in order to observe diel and lunar cycles. Fish larvae entered the lagoon at dusk and at night, mainly during moonless periods. Colonization was closely related to decreasing light intensity; it was 4 times greater during new moon than during full moon. Other environmental factors such as hydrodynamic features of the water mass above and in front of the reef crest may have also influenced this colonization. More than $97 \%$ of the larvae that colonized the lagoon were postflexion or later stage larvae and were probably competent to settle in the lagoon. Gobiidae were the most numerous with $60.5 \%$ of the catches. Scaridae and Labridae were the second and the third most important families with 10.3 and $6.2 \%$ of the catches respectively.
\end{abstract}

KEY WORDS: Recruitment - Reef fish larvae - Temporal cycles

\section{INTRODUCTION}

Like most marine fishes, coral reef fishes have a larval pelagic phase which ends with settlement onto the reef. The success of this transition between 2 very different environments determines the fishes' settlement levels. Research on coral reef fishes has recently focused on the settlement period as this is important for the dynamics of the reef fish populations (Victor 1983, Richards \& Lindeman 1987, Doherty \& Williams 1988, Jones 1990, Robertson 1992). A number of different methods have been used to better understand both the pelagic and the benthic life of reef fishes. Some of these studies have been conducted on young fishes, just after their settlement onto the reef. Recruitment patterns at different time and space scales have been estimated using in situ censuses on newly settled fishes (Williams 1983, Eckert 1984, Sale et al. 1984). Light trapping has also been used recently to catch larvae on or near reefs (Doherty 1987, Milicich 1988), but this technique relies upon an active process at night (positive phototropism) which can vary between species and developmental stages (Thorrold 1992).
Daily otolith increments give valuable information on the duration of the pelagic life (reviewed by Victor 1991) but this is an indirect method for studying the timing of settlement. Data collected with plankton tows have also enhanced knowledge of larval distribution in the water column surrounding reefs (Victor 1984, Williams 1986, Kingsford \& Choat 1989, Kobayashi 1989, Leis et al. 1991). These results have given a good description of the horizontal and vertical distributions of fish larvae around reefs (Leis 1986, Leis 1991a, Boehlert et al. 1992), but have been hindered by problems of avoidance by larger larvae and difficulty in identifying smaller larvae.

The above methods have provided much information on the distribution and abundance of fish larvae but most of them fail to take into account the short period from the end of the pelagic phase to the beginning of the reef-associated phase. There is still a gap in data on recruitment obtained by these methods because they do not cover this period. Some papers have previously pointed out that the mechanisms of larval transport between the ocean and the reef are unknown (McFarland \& Odgen 1985, Sweatman 1985, Richards 
\& Lindeman 1987). This transport of fish larvae which occurs just before settlement is referred to as 'colonization' in the present paper. Very few methods can be used to observe this colonization because these larvae move between 2 different environments. One method is to follow the larvae from the water column until they settle onto the benthic environment, but only a few larvae can be observed and this seems difficult to do on a regular basis. A second method is to catch larvae as they pass through the interface between the ocean and the reef (Dufour 1991). This assumes that fish larvae are caught only during colonization onto the reef and not while moving back from the reef to the ocean or staying in 1 of the 2 environments. The aim of this study is to describe the colonization pattern to a lagoon by reef fish larvae at a small temporal scale using this second method.

\section{MATERIALS AND METHODS}

Study area. Moorea Island $\left(17^{\circ} 30^{\prime} \mathrm{S}, 149^{\circ} 5^{\prime} \mathrm{W}\right)$ is a high volcanic island, located in the Society Archipelago (French Polynesia), surrounded by a coral reef which delimits a lagoon (Fig. 1). A fringing reef is located along the shore of the island. The barrier reef is formed by a reef flat of $2 \mathrm{~m}$ depth in the most internal part and bordered by a reef crest on the outer part which is the frontier between the lagoon and the ocean. The crest is almost permanently at sea level due to very weak tides (annual maximum range $0.3 \mathrm{~m}$ ).

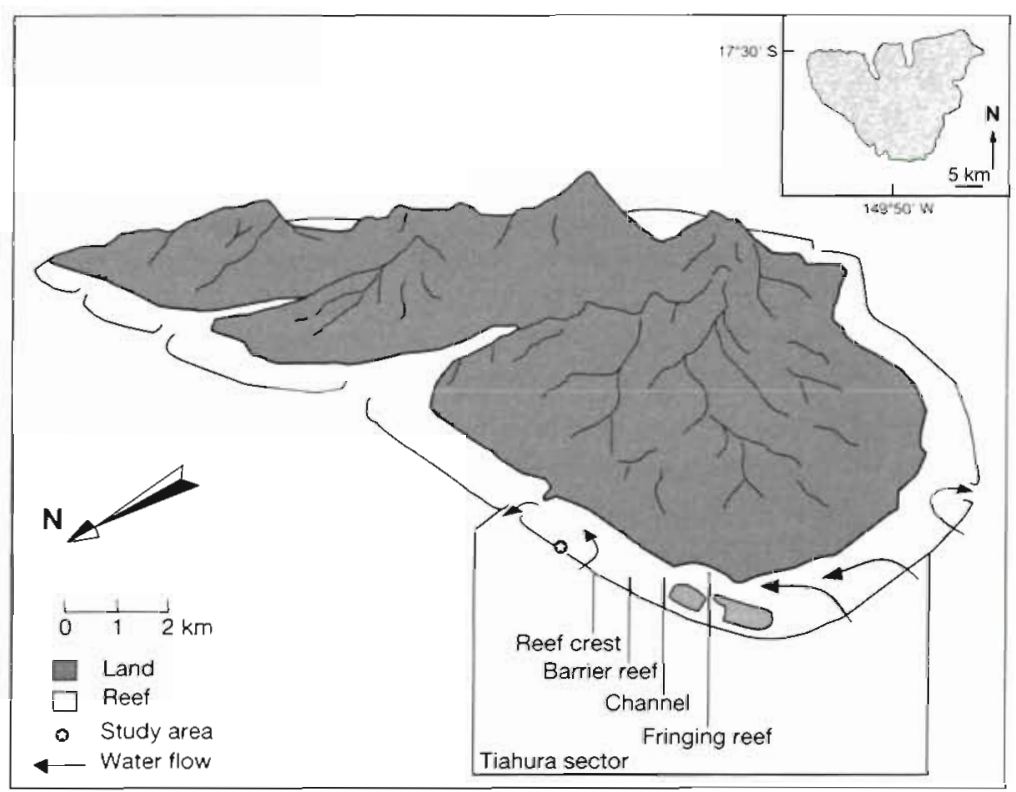

Fig. 1. Moorea Island. French Polynesia, showing the sampling location on the reef crest. Arrows indicate the main stream lines
Waves breaking on the crest create a constant flux of ocean water across the reef crest. The outer slope is located seaward of the reef crest, and ends in a sandy bottom at $30 \mathrm{~m}$. The bottom then becomes very steep and drops to the oceanic floor, more than $2000 \mathrm{~m}$ deep. The reef crest is intersected by passes connecting the open ocean with a lagoon channel. Through these passes, lagoon water, which comes from waves breaking over the crest, flows back into the ocean. Thus, the predominant hydrodynamic feature of this reef is a permanent flow of oceanic water over the crest and the barrier reef which goes back to the ocean through the channel and the passes. The average residence time of the water in this system is $6 \mathrm{~h}$ (Delesalle \& Sournia 1992). The present study was carried out on the reef crest, in the northwestern part of the island (Tiahura sector; Fig. 1). The distance between the crest and the shore is $840 \mathrm{~m}$. The nearest pass is located $600 \mathrm{~m}$ from the study area on the reef crest. The current flushing out of the pass has an average speed of $0.5 \mathrm{~m} \mathrm{~s}^{-1}$ but can reach $2 \mathrm{~m} \mathrm{~s}^{-1}$ (Lenhardt 1991).

Sampling methods. Larvae were sampled on the reef crest using a single net fixed directly on the substrate. The net was located in the surf zone at the highest point of the crest. The lack of replication through space was due to the difficult access to the crest, especially at night. Therefore, replication was provided through time by several temporal cycles. The size of the mouth of the nets $(0.25 \times 1 \mathrm{~m})$ was chosen according to the average water depth on the crest $(0.15 \mathrm{~m})$. The mesh size of the net was $0.5 \mathrm{~mm}$. Other factors such as wind direction were qualitatively recorded during the sample periods. Larvae were collected over 3 periods (May-June 1988, March-June 1989 and September-November 1989). Three time cycles were investigated: $24 \mathrm{~h}$ $(n=4), 48 h(n=3)$ and lunar $(n=4)$. The $24 \mathrm{~h}$ cycles were studied in May and June 1988 and the $48 \mathrm{~h}$ cycles were studied during a single lunar month in April 1989. Individual samples were taken by attaching the cod end to the net for $10 \mathrm{~min}$. The interval between samples was $1 \mathrm{~h}$ during $24 \mathrm{~h}$ cycles (30 min at dusk and dawn) and $2 \mathrm{~h}$ during $48 \mathrm{~h}$ cycles ( $1 \mathrm{~h}$ at dusk and dawn). The lunar cycles represent 2 pairs of running cycles in April and May and in September and October 1989. The first pair covered more than 2 cycles, while the last Iunar cycle of the second part was not completed due to bad weather. The lunar cycles comprised 2 nights of sampling each week for $4 \mathrm{wk}$. Samples were taken each night 3 times (20:00, 22:00 and 00:00 h) for $10 \mathrm{~min}$ each. Water flux was measured 
by a General Oceanics flowmeter attached to the frame of the net. The net was rarely clogged due to low turbidity and turbulent water flowing into the net. Larvae were fixed with $10 \%$ formalin in seawater. Since the relation between larval flux and water flow on the reef crest is not clearly understood (Dufour 1991) and because this sampling method is not comparable to towed net sampling, we do not present the results as density of larvae per $\mathrm{m}^{3}$. Instead, we present the larval flux, which is the actual number of larvae coming into the lagoon per unit of time and crest length, further expressed as 'number of larvae per $10 \mathrm{~min}$ and per $\mathrm{m}$ of reef crest' (see Igushi \& Mizuno 1990 for a similar expression). The water flow through the net is also presented for comparison with the larval flux.

Taxonomic analysis. The first part of the 'Results' presents a taxonomic analysis based on the samples from the cycles taken in 1989. Larvae were sorted, under a dissecting microscope, from the other materials collected and stored in $5 \%$ formalin in seawater. Identification of the larvae has been done at the lowest taxonomic level possible following Leis \& Rennis (1983) and Leis \& Trnski (1989). Almost all the larvae were identified to the family level although determination of genus and species was possible in some instances. The postflexion larval types were identified within families corresponding to consistently recognizable differentiations in their morphological traits or pigment patterns, but without identification to species or genus. Types are indicated with a number following the family name. The preflexion and flexion stages were pooled into 1 larval type called 'preflexion' in this paper. Juvenile specimens of all families were also pooled into 1 type called 'juvenile' except for Pomacentridae and Apogonidae because many of the latter 2 families were at this stage. The taxonomic analysis is based on a comparison among 4 periods of the diel and lunar cycles: day (06:00 to $17: 30 \mathrm{~h}$ ), dusk (18:00 to 19:00 h) and the moonlit and moonless periods of night.

\section{RESULTS}

\section{Taxonomic analysis}

Larvae of 50 of the 75 families of fishes identified for the Society Archipelago (Randall 1985) were found in our samples (Table 1). All but 6 were reef inhabitants; the others were oceanic families. Among all families, 37 genera and 6 species were identified. One subfamily (Amblyopinae) was not previously reported in French Polynesia. More than $80 \%$ of the reef fish families were of postflexion stage or older, while twothirds of the oceanic families were at the preflexion stage only. Among the 4 families that were not captured at the postflexion stage, 2 were shorefishes (Carangidae, Mugilidae). We did not capture any Holocentridae larvae at the postflexion stage; all specimens had metamorphosed and we pooled them with other juveniles. The dominance of old larvae was confirmed: $97.5 \%$ of the total number of fishes caught on the crest were in postflexion stage or older. Most of the larvae were therefore probably competent to settle into the lagoon. The taxonomic analysis was made for the 4 different periods identified as distinct levels of larval flux over the reef crest: day, dusk, and moonlit and moonless periods during the night. Only those larval types exceeding 10 individuals for each period are presented but the total number represents all the larvae caught during each period.

The comparison between day and dusk showed that very few larval types were present during the day (Fig. 2). Only 3 types had more than 10 individuals among which Blenniidae type 1 was the most important. After sunset, the diversity of larvae increased; 21 larval types had 10 individuals or more, and 6 types had more than 100 specimens. The first family coming over the reef at dusk was the Blenniidae, when most other fish larvae were not as numerous, except Gobiidae and, to a lesser extent, Scaridae and Scorpaenidae. The most numerous type was Gobiidae type 1, identified as Asteropteryx semipunctatus, with 154 individuals collected. Preflexion larvae (all taxa pooled) were not abundant; only 20 were captured. The most important family was Gobiidae with $23 \%$ of the catches, followed by Labridae and Scorpaenidae. The moonlit periods (Fig. 2) displayed total abundance and diversity roughly similar to the samples collected at dusk although many more samples were taken during this period (138 vs 48). However, the main larval types differed greatly between the 2 periods. Gobiidae was still the most important family during this period with $53 \%$ of the catches. Preflexion larvae were much more abundant during moonlit nights (100 vs 20 specimens) but this could be biased by the difference in number of samples. They were however the second most numerous larval type after Gobiidae. Scaridae and Labridae with 10 and $7 \%$ of the catches respectively were also important. The Shannon-Weaver index of diversity was 1.57 . The families sampled on the reef crest during moonless periods were roughly identical to those sampled at dusk but Blenniidae was less abundant. The moonless period presented a larger number of larvae than the moonlit period, although the number of samples was roughly similar (133 vs 138). The total abundance of larvae was higher during moonless than during moonlit samples (6744 vs 1688). Among the 37 identified types, 13 have more than 100 specimens and the Shannon-Weaver index of diversity was 4 . The main families were Gobiidae (62\%), Scaridae (11\%), Labridae (7\%) and 
Table 1. Taxonomic list of fish larvae collected on the reef crest of Moorea Island, French Polynesia. Asterisks indicate pelagic families

\begin{tabular}{|c|c|c|c|}
\hline \multirow[t]{2}{*}{ Family } & \multicolumn{2}{|c|}{ No. of: } & \multirow[t]{2}{*}{ Identified genus (species) } \\
\hline & Postflexion types & Preflexion types & \\
\hline Acanthuridae & 2 & 1 & Zebrasoma, Acanthurus \\
\hline Antennariidae & 1 & 0 & Antennarius \\
\hline Apogonidae & 5 & 4 & Fowleria \\
\hline Balistidae & 0 & 3 & \\
\hline Belonidae & 0 & 2 & \\
\hline Blenniidae & 3 & 2 & Enchelyurus \\
\hline Bothidae & 1 & 0 & \\
\hline Bythitidae & 2 & 0 & Brosmophyciops, Dinematichthys \\
\hline Callionymidae & 1 & 0 & \\
\hline Carangidae & 0 & 2 & Selar \\
\hline Chaetodontidae & 1 & 1 & \\
\hline Chanidae & 1 & 0 & Chanos (C. chanos) \\
\hline Clupeidae & 1 & 1 & \\
\hline Coryphaenidae* & 0 & 1 & Coryphaena \\
\hline Creedidae & 1 & 0 & \\
\hline Elopidae & 2 & 0 & Elops, Albula \\
\hline Engraulididae & 1 & 0 & \\
\hline Exocoetidae" & 0 & 1 & \\
\hline Gobiidae & 15 & 1 & Asteropteryx (A. semipunctatus) \\
\hline s.F. Amblyopinae & 1 & 0 & \\
\hline Gonostomatidae ${ }^{*}$ & 1 & 0 & Cyclothone \\
\hline Holocentridae & 1 & 1 & \\
\hline Isonidae & 0 & 1 & Iso (I. hawaiiensis) \\
\hline Kraemeriidae & 1 & 0 & Kraemeria \\
\hline Labridae & 6 & 0 & \\
\hline Lethrinidae & 1 & 1 & Lethrinus \\
\hline Lutjanidae & 1 & 1 & Lutjanus \\
\hline Microdesmidae & 1 & 1 & Gunnellichthys \\
\hline Mugilidae & 0 & 1 & \\
\hline Mullidae & 1 & 0 & \\
\hline Muraenidae & 1 & 0 & Gymnothorax \\
\hline Myctophidae' & 4 & 3 & Ceratoscopelus, Lampanyctus, Myctophum \\
\hline Ostraciidae & 0 & 1 & \\
\hline Ophichthidae & 1 & 0 & \\
\hline Pempheridae & 0 & 1 & Pempheris ( $P$. oualensis) \\
\hline Pinguipedidae & 1 & 1 & Parapercis \\
\hline Pleuronectidae & 1 & 0 & Samariscus (S. triocellatus) \\
\hline Pomacentridae & 4 & 0 & Pomacentrus, Abudefduf \\
\hline Priacanthidae & 0 & 1 & Priacanthus \\
\hline Scaridae & 1 & 0 & \\
\hline Schindleriidae & 1 & 0 & Schindleria (S. praematura) \\
\hline Scorpaenidae & 3 & 0 & \\
\hline Scombridae ${ }^{*}$ & 0 & 1 & Thunnus \\
\hline Serranidae & 2 & 2 & Cephalopholis, Epinephelus, Anthias, Pseudogramma \\
\hline Soleidae & 1 & 0 & Aseraggodes \\
\hline Sphyraenidae & 1 & 1 & Sphyraena \\
\hline Syngnathidae & 1 & 0 & \\
\hline Synodontidae & 1 & 0 & \\
\hline Tetraodontidae & 1 & 0 & Canthigaster \\
\hline Tripterygiidae & 1 & 3 & \\
\hline
\end{tabular}

also juvenile fishes $(7 \%)$ among which half were Pomacentridae. Therefore, most of the larval types and stages were more abundant during moonless samples than during moonlit samples, except preflexion larvae. Thus, the increase of the larval flux from moonlit to moonless periods was due to an increase of all postflexion larval types.

\section{Diel cycles}

The influx of larvae into the lagoon over the reef crest was always very low during daylight (Fig. 3). It increased rapidly at dusk (18:00 h) and at night although it varied both within and between nights. Larval flux increased during the first part of the night in some 
Fig. 2. Histogram of the taxa collected over the reef crest during the 4 periods: daylight, dusk, and moonlit and moonless periods of night. The total number of larvae of each period includes all larvae sampled during the period. Only larval types with at least 10 individuals are presented. Numbers following the family names represent the different larval types (e.g. Gobiidae 1: Asteropteryx semipunctatus)
Day: 36 samples
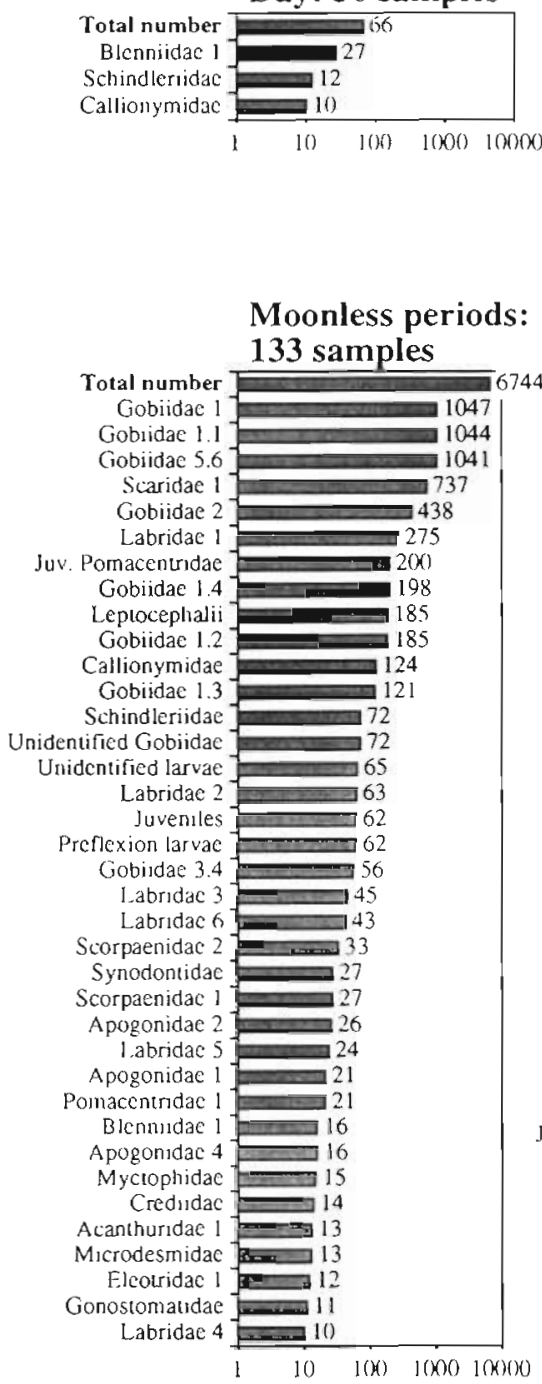

Dusk: 48 samples

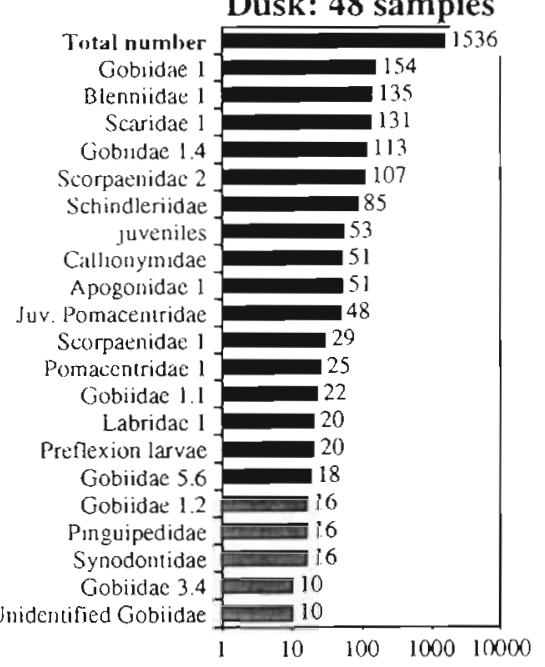

Moonlit periods: 138 samples

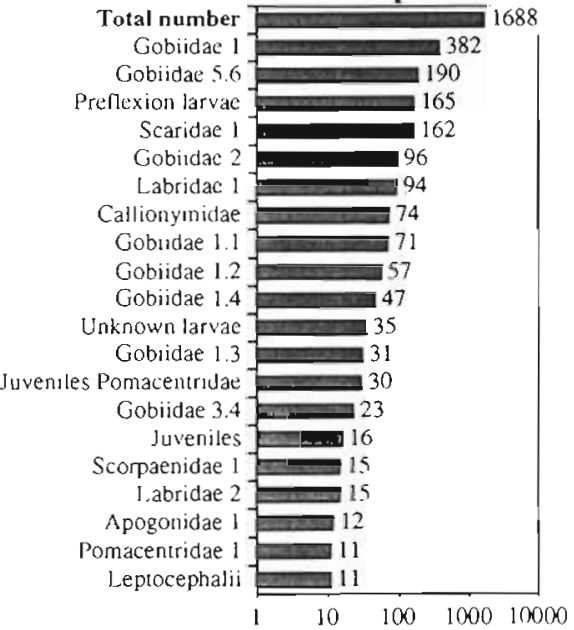

instances (Fig. 3A, C), but in other instances the flux decreased during the beginning of the night and increased afterwards (Fig. 3B). Peaks of larval flux occurred during moonless periods of the night for 3 cycles; 2 peaks occurred at the beginning of the night (Fig. 3A, C) and the third occurred after the moonlit period (02:00 h; Fig. 3B). The last of the 4 cycles presented a different pattern (Fig. 3D). Larval flux was very weak during the entire night and was not associated with the moonless period. Larval flux was much lower than during the other cycles and was negligible around midnight. Water flow usually showed no difference between day and night. Water flow was similarly not correlated with the larval flux except during 1 lunar cycle where a positive correlation at $\mathrm{p}<0.05$ were found (Table 2). The low water flow of the fourth cycle was associated with a change in trade wind direction. This cycle occurred during southeast winds, while the previous cycles were investigated with northeast trade winds, which prevail during winter. This diel pattern of colonization was roughly constant through the period of sampling (May to June 1988).

Table 2. Kendall rank correlation coefficient $(\tau)$ between larval flux and the water flux. ns: not significant, $p<0.05$, $\cdots p<0.01, \cdots p<0.001$

\begin{tabular}{|lccc|}
\hline $\begin{array}{l}\text { Range of } \\
\text { T-values }\end{array}$ & $\begin{array}{c}24 \mathrm{~h} \text { cycles } \\
(4 \text { cycles })\end{array}$ & $\begin{array}{c}48 \text { h cycles } \\
(3 \text { cycles })\end{array}$ & $\begin{array}{c}\text { Lunar cycles } \\
(4 \text { cycles })\end{array}$ \\
\hline Cycle 1 & $-0.19 \mathrm{~ns}$ & $-0.22 \mathrm{~ns}$ & $0.06 \mathrm{~ns}$ \\
Cycle 2 & $-0.26 \cdot$ & $-0.1 \mathrm{~ns}$ & $0.37 \cdots$ \\
Cycle 3 & $-0.03 \mathrm{~ns}$ & $+0.02 \mathrm{~ns}$ & $0.2 \mathrm{~ns}$ \\
Cycle 4 & $-0.11 \mathrm{~ns}$ & & $0.5 \cdots$ \\
\hline
\end{tabular}



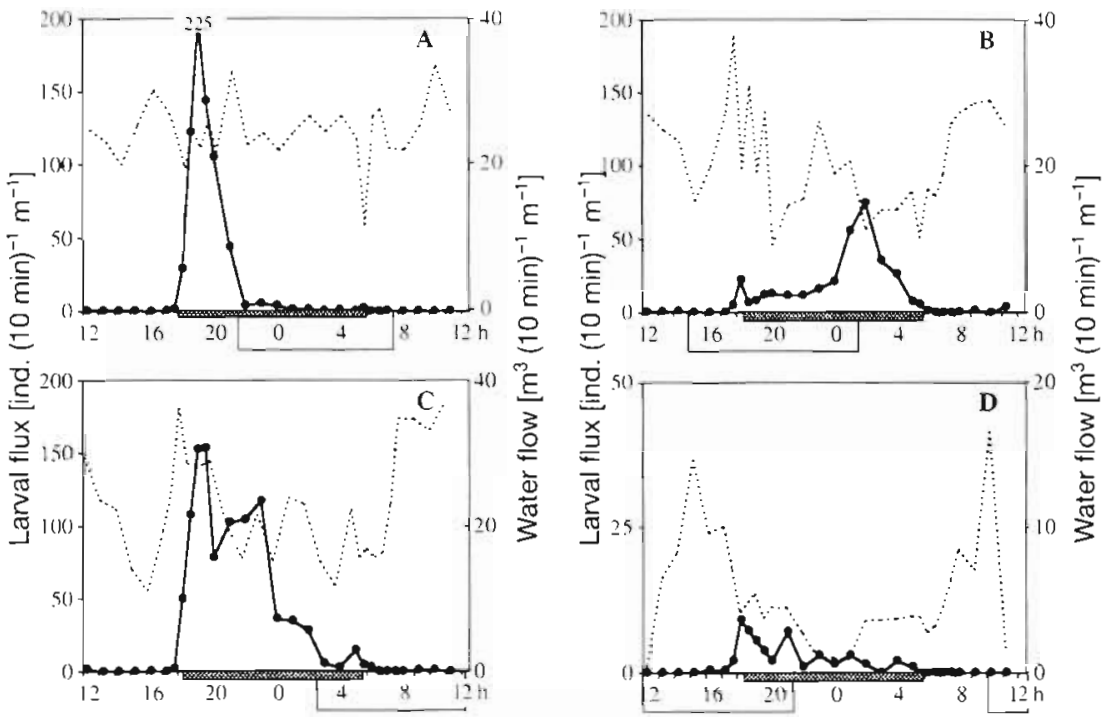

Fig. 3. 24 h cycles on the reef crest: $(\bullet-)$ larval flux for each sample; (...) measured water flow in the net. Night hours are shaded, periods when moon is risen are framed. (A) 5 May 1988; (B) 24 May 1988; (C) 9 June 1988; (D) 17 June 1988 increased at dusk (about 20 min after sunset), and the values ranged from 10 to 40 larvae $\left(10 \mathrm{~min}^{-1} \mathrm{~m}^{-1}\right.$. During the night, larval flux depended mainly on moon phase, being significantly higher during moonless periods than during moonlit periods (Table 3). Flux was generally highest $[450$ larvae $\left(10 \mathrm{~min}^{-1} \mathrm{~m}^{-1}\right]$ when the moonless period immediately followed dusk. The high larval flux continued most of the night and decreased at the beginning of the moonlit period or at dawn, depending on the moon phase. It is worth noting that the night larval flux was always higher during moonless than moonlit periods over the ten $24 \mathrm{~h}$ cycles presented and that the flux at dusk seems roughly constant and much higher than at dawn.
In order to assess variations of larval flux and water flow among consecutive days, sampling was performed over 48 h cycles ( 3 sets of 2 running diel cycles, Fig. 4). The larval flux was again low during the day and increased markedly at dusk, and also varied in magnitude according to the moon period. New moon periods showed peaks of larval flux during the first night. The water flow was not correlated with the larval flux during this cycle (Fig. 4A, Table 2). The highest larval flux during the first moon quarter was recorded at dusk for both nights. A very low water flow occurred at the same time but is however not significantly correlated with larval flux over the entire cycle (Fig. $4 \mathrm{~B}$, Table 2). The following moonlit period showed a low larval flux. After the moon set, the number of larvae increased slightly for the 2 nights but it was still low relative to larval flux during the new moon. The last cycle was studied during the full moon (Fig. 4C). Two peaks of larval flux occurred at dusk before the 2 nights where larval flux was very low and when moonlight lasted the entire night. Here too, water flow did not consistently influence the larval flux during this cycle (Table 2).

Samples collected over 1 or 2 diel cycles during different moon phases showed several features of the colonization of the lagoon by fish larvae. The larval flux over the reef crest was negligible during the daylight period (05:00 to 17:00 h). This flux
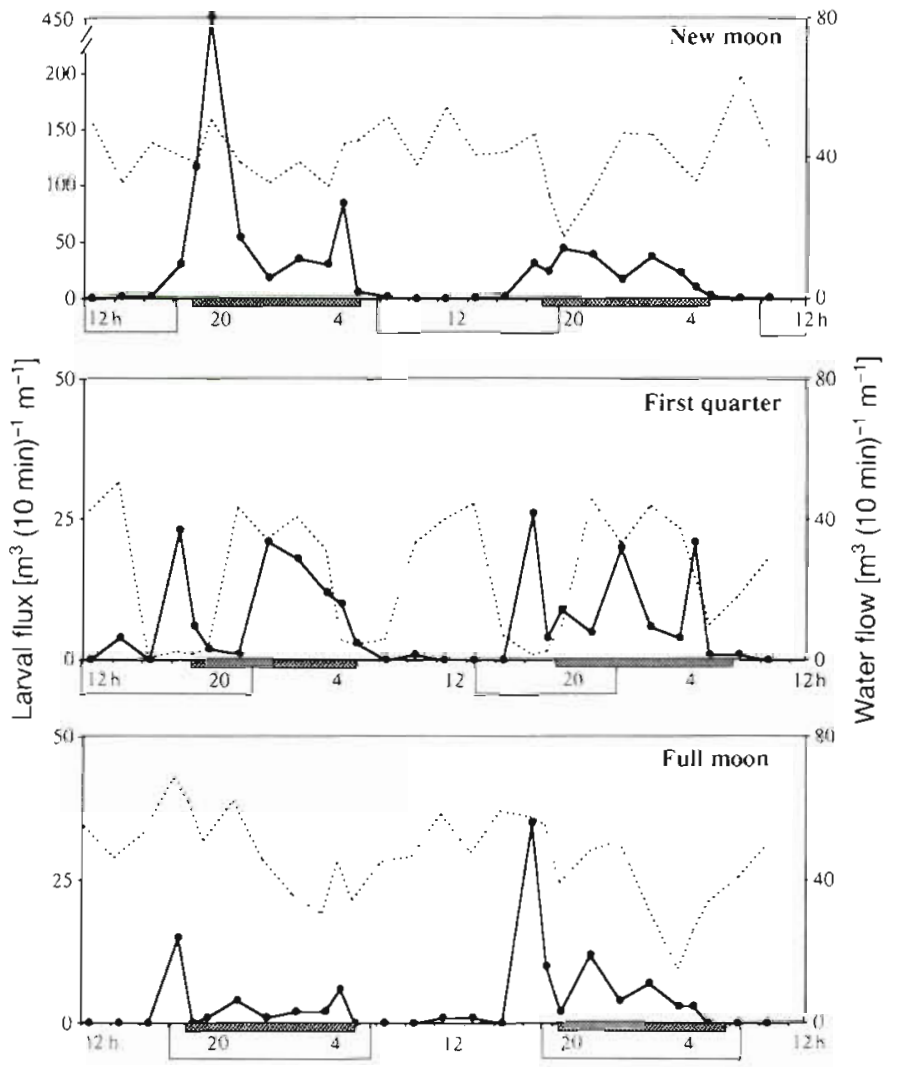

Fig. 4. 48 h cycles on the reef crest during a single lunar month in April 1989. (-) larval flux for each sample; (----) measured water flow in the net. Night hours are shaded, periods when moon is risen are framed 
Table 3. Mann-Whitney $U$-test for differences between the mean larval flux [no. larvae $(10 \mathrm{~min})^{-1} \mathrm{~m}^{-1}, \pm \mathrm{SE}$ ] of samples made during moonlit periods and moonless periods of the night. $Z$ : SE of the $U$ variable; $" p<0.05, \cdots p<0.01, \cdots p<0.001$

\begin{tabular}{|lccc|}
\hline & $\begin{array}{c}24 \mathrm{~h} \\
\text { cycles }\end{array}$ & $\begin{array}{c}48 \mathrm{~h} \\
\text { cycles }\end{array}$ & $\begin{array}{c}\text { Lunar } \\
\text { cycles }\end{array}$ \\
\hline Moonlit larval flux & $8( \pm 2)$ & $4( \pm 0.78)$ & $13( \pm 2.9)$ \\
Moonless larval flux & $57( \pm 11)$ & $40( \pm 22.35)$ & $40( \pm 8)$ \\
$Z$ & -2.5 & $-3.2 \cdots$ & $-5 \cdots$ \\
\hline
\end{tabular}

\section{Lunar cycles}

Results of larval flux compared to lunar cycles are presented in Fig. 5. A common pattern of greater larval flux during moonless nights was found during the lunar cycles. Several peaks of larval flux occurred around the new moon phase (moonless nights). Periods of low or null larval flux occurred during or before the full moon phases (moonlit nights). Larval flux just before the full moon was usually lower than after the full moon. Because the larvae were collected between 20:00 and 00:00 $\mathrm{h}$, the first moon and last moon quarters were sampled during moonlit and moonless periods respectively. This probably accounted for the fact that first moon quarter presented a lower larval
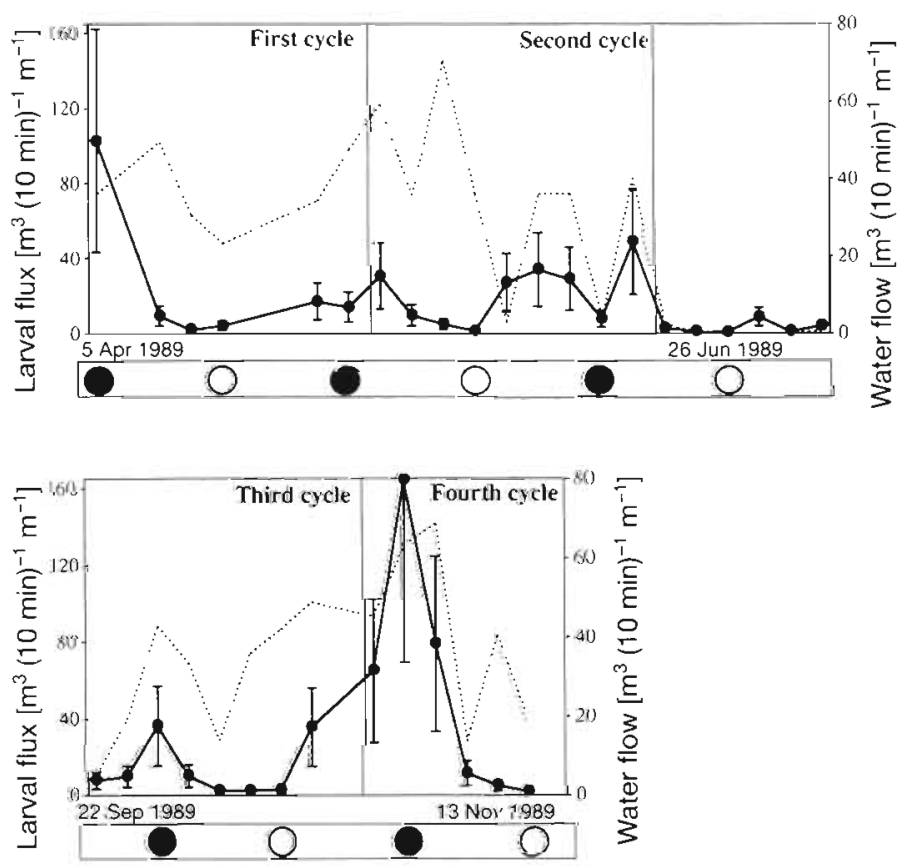

Fig. 5. Lunar cycles ( new moon, O full moon) sampled between April and June 1989 and between September and November 1989 $(\rightarrow-)$ mean larval flux $( \pm \mathrm{SE})$ averaged over 3 samples each night; (....) water flow, also averaged over 3 samples each night flux than the last moon quarter. The new moon peaks of larval flux were different among cycles. The highest peaks of the first and the fourth cycles are close to the summer season (from November to March), while the smaller peaks appear near the winter season (from June to September). Water flow was not correlated with the larval flux except for the second and fourth cycles where both larval flux and water flow were high during few samples (Table 2). The average abundances of larvae between the 2 periods (i.e. moonless and moonlit periods) were significantly different (Table 3). Therefore, a general trend of lower larval flux around winter appears in the evolution of these cycles, over the lunar pattern of peaks around the new moon.

\section{DISCUSSION AND CONCLUSIONS}

This study shows that the colonization of the reef crest by reef fish larvae is mainly a nocturnal process. There are few other observations of the diel timing of settlement of fish larvae on the reef substrate (Dufour 1991, Victor 1991). It has been shown that the settlement of the acronurus larvae of Acanthuridae occurs at night (Sale 1969, McFarland \& Odgen 1985), as well as some Pomacentridae (Doherty 1981, Sweatman 1985, Robertson et al. 1988). These observations concern only 2 families and, although more studies were recommended on this subject (McFarland \& Odgen 1985), few results have actually been published. Our results support the hypothesis that most reef fish larvae enter the reef at night. The colonization of nearshore waters by some other temperate fishes is also a nocturnal process (Boehlert \& Mundy 1987, Lough \& Bolz 1989) The requirements for environmental conditions is however unknown for almost all fish species. The early colonization at dusk by Blenniidae gives evidence that behind the general pattern of nocturnal colonization, the observed variations among families could reflect differences in habitat selection (Connell \& Jones 1991) or some particular behavior during this process (Breitburg 1991).

Nevertheless, it is legitimate to question whether the observed pattern is a bias of the sampling procedure. It could be presumed that avoidance of the sampling gear by fish larvae during the day could produce these data. We argue that several features of the sampling method rule out such a bias. First, the frame of the net is fixed on the reef crest and there is no element in front of the net that could be detected by fish larvae. Second, the water flow is highly 
turbulent just after breaking with linear speeds varying between 1 and $4 \mathrm{~m} \mathrm{~s}^{-1}$, depending of the wave height (Jansen 1986). These larvae are certainly unable to swim against such a flow (Blaxter 1986). Third, the high number of larvae and juveniles taken at dusk is counter to the hypothesis of a visual avoidance during daylight periods because light intensity at this time would also allow visual avoidance of the net. Finally, breaking waves create numerous air bubbles which reduce the visual field to a few decimeters. Thus, visual avoidance of the net by fish larvae would probably not determine the observed pattern.

Colonization concerns mainly postflexion larval stage and juvenile stage. The precise timing of colonization seems consistent with the fact that specimens at these stages do not drift passively over the crest. Near the surf zone, the positioning of fish larvae is probably an active process (Whitfield 1989), mainly for old fish larvae because they have good locomotive ability (Webb \& Weihs 1986). As settlement is most probably an active process, we presume that most of the postflexion larvae and juvenile fishes are able to control the time at which they enter the lagoon. This phenomenon might explain why larval flux did not seem to vary consistently with water flow at different time scales. Preflexion stage larvae do not present the same pattern. They are more likely to drift passively over the reef crest. Most of the studies on settlement, dealing with observation of specimens on patch reefs, have not quantified water currents around their study area in order to assess their influence on larval recruitment. In this study, we presented water flow measurement because we believe that this factor could influence larval colonization. However, the correlation between larval flux and water flow is not constant in our samples. This flow depends mainly on the wave height. Whether this water mass comes from surface water or deep water is unknown and, thus, we do not know whether fish larvae outside the reef are located near the surface or above the bottom. It is, therefore, not surprising that little direct evidence exists for the influence of water flow on larval flux because this may be difficult to measure accurately. While hydrodynamic features on the reef crest can probably affect the observed pattern, it cannot account for the observed diel and lunar cycles.

Other environmental factors may affect colonization. The last $24 \mathrm{~h}$ cycle let us presume that wind direction may have influenced the larval flux over the reef crest. The wind blowing offshore could have reduced the larval flux. This finding is consistent with the fact that larval fish have usually been found to be less abundant on leeward than on windward sides of islands (Leis 1991b). Environmental factors are therefore able to modify strongly the pattern of colonization at the observed scales (i.e. diel and lunar). However, none except light can really explain the observed pattern because they do not present the observed cyclic variations.

The avoidance of the reef crest and the sea surface by fish larvae during daylight periods could have caused the observed pattern. Our results indicate that colonization is a response to a lowering of light intensity. The variation of ambient light can be viewed as a signal inducing a behavioral change in reef fish larvae. The response of fish larvae seems to be proportional to the temporal gradient of light because the highest peaks of colonization occur after the strongest decrease of ambient light, when the day is followed by a moonless night. This is a well-known phenomenon explaining daily vertical migrations of fish larvae in the ocean (Enright 1977, Enright \& Honneger 1977, Neilson \& Perry 1990), and of zooplankton over coral reefs after a decrease in sunlight or moonlight intensity (Alldredge \& King 1980, Tranter et al. 1981). Zooplankton appear over the reef crest mainly at night but they are thought to be passively transported by water flux coming with breaking waves (Hobson \& Chess 1978, 1986). However, these studies, based on planktonic invertebrates, have not investigated fish larvae.

The colonization of the reef at night could also result from a predatory impact on a permanent flow of larvae coming from outside. Although no direct observations can exclude a predatory effect, several features of this colonization argue that this pattern is not the result of a predation during the day. Hamner et al. (1988) suggested that a high number of fishes creates a 'wall of mouths' foraging on zooplankton during the day at Davies Reef (Great Barrier Reef). Similar predation is improbable at Moorea, however. The density of fish over the reef front of Moorea Island (2.2 to 5.2 ind. $\mathrm{m}^{-2}$; Galzin 1987a) is much lower than that over Davies Reef (14.3 to 24 ind. $\mathrm{m}^{-2}$; Hamner et al. 1988).

The activity rhythm of the other reef dwellers also shows diel cycles. Among them, small piscivorous fishes are probably the most abundant predators for young settling fishes (Randall \& Brock 1960, Harmelin-Vivien 1981). Nocturnal fishes of French Polynesia, with only $37 \%$ of the species, are less abundant than diurnal species (Galzin 1987b) although all of them colonize the lagoon at night. It is supposed that the foraging activity of fishes is much less important during moonless nights than during moonlit nights and that the timing of the changeover of the 2 guilds at dusk presents a 'safety corridor' when the first guild has already found shelter and the second is not yet in the water column (Hobson 1965, 1973, Johannes 1981). Therefore, there may exist a link between the peaks of colonization at dusk and during moonless nights and these activity cycles of larval fish predators. Previous 
studies about the timing of planktonic migrations have also suggested that predation could be the force that formed this pattern (Enright 1977, Tranter et al. 1981, Bollens et al. 1992).

The pattern of colonization probably enhances the survival rate of fish larvae but the mortality is probably very important during the period following the colonization (Doherty \& Sale 1986, Victor 1986, Shulman \& Ogden 1987, Dufour \& Galzin 1992). More studies are required to understand the mechanisms by which fish larvae cross the interface between the ocean and the reef and what mechanisms control the success of this colonization.

Acknowledgements. Samples were collected with the help of M. K. El Moudni. We thank J.-P. Gattuso, B. Delesalle, J. Leis, A. Sabates, M.-P. Olivar, G. Boehlert and B. Mundy for helpful critics on earlier drafts of the manuscript.

\section{LITERATURE CITED}

Alldredge, A. L., King, J. M. (1980). Effects of moonlight on the vertical migration patterns of demersal zooplankton. J. exp. mar. Biol. Ecol. 44: 133-156

Blaxter, J. H. (1986). Development of sense organs and behaviour of teleost larvae with special reference to feeding and predator avoidance. Trans. Am. Fish. Soc. 115: $98-114$

Boehlert, G. W., Mundy, B. C. (1987). Recruitment dynamics of metamorphosing English sole, Parophorys vetulus, to Yaquina bay, Oregon. Estuar. Coast. Shelf Sci. 25: 261-281

Boehlert, G. W., Watson, W., Sun, C. (1992). Horizontal and vertical distributions of larval fishes around an isolated oceanic island in the tropical Pacific. Deep Sea Res. 39 $439-466$

Bollens, S. M., Frost, B. W., Thoreson, D. S., Watts, S. J. (1992). Diel vertical migration in zooplankton: field evidence in support of the predator avoidance hypothesis. Hydrobiol. 234: $33-39$

Breitburg, D. L. (1991). Settlement patterns and presettlement behavior of the naked goby, Gobiosoma bosci, a temperate oyster reef fish. Mar. Biol. 109: 213-221

Connell, J. H., Jones, G. P. (1991). The influence of habitat complexity on postrecruitment processes in a temperate reef fish population. J. exp. mar. Biol. Ecol. 151: $271-294$

Delesalle, B., Sournia, A. (1992). Residence time of water and phytoplankton biomass in coral reef lagoons. Cont. Shelf Res. 12: 939-949

Doherty, P. J. (1981). Coral reef fishes: recruitment-limited assemblages? Proc. 4th int. coral Reef Congr. 2: 465-470

Doherty, P. J. (1987). Light traps: selective but useful devices. Bull. mar. Sci. 41: 423-431

Doherty, P. J., Sale, P. F. (1986). Predation on juvenile coral reef fishes: an exclusion experiment. Coral Reefs 4 : $225-234$

Doherty, P. J., Williams, D. McB. (1988). The replenishment of coral reef fish populations. Oceanogr. mar. Biol. A. Rev. 26: $487-551$

Dufour, V. (1991). Variations d'abondance des larves de poissons en milieu récifal: effet de la lumière sur la colonisation larvaire. C.r. Acad. Sci. Paris, Série III 313: $187-194$

Dufour, V., Galzin, R. (1992). Le recrutement des poissons récifaux de Polynésie française, impact sur la dynamique des peuplements et conséquences sur la gestion des stocks. Cybium 16: 267-277

Eckert, G. J. (1984). Annual and spatial variation in recruitment of labroid fishes among seven reefs in the Capricorn Bunker group, Great Barrier Reef. Mar. Biol. 78: 123-127

Enright, J. T (1977). Diurnal vertical migration: adaptative significance and timing. Part 1 Selective advantage: a metabolic model. Limnol. Oceanogr. 22: 856-872

Enright, J. T., Honegger, H.-W. (1977). Diurnal vertical migration: adaptative significance and timing. Part 2. Test of the model: detail of timing. Limnol. Oceanogr. 22: 873-886

Galzin, R. (1987a). Structure of fish communities of French Polynesia coral reefs. I. Spatial scales. Mar. Ecol. Prog. Ser. 41: $129-136$

Galzin, R. (1987b). Structure of fish communities of French Polynesia coral reefs. II. Temporal scale. Mar. Ecol. Prog Ser. 41: 137-145

Hamner, W., Jones, M. S., Carleton, J. H., Hauri, I. R., Williams, D. McB. (1988). Zooplankton, planktivorous fishes and water currents on a windward reef face: Great Barrier Reef, Australia. Bull. mar. Sci. 42: 459-479

Harmelin-Vivien, M. L. (1981). Trophic relationship of reef fishes in Tulear (Madagascar). Oceanol. Acta 4: 365-374

Hobson, E. S. (1965). Diurnal-nocturnal activity of some inshore fishes in the Gulf of California. Copeia 65: 291-302

Hobson, E. S. (1973). Diel feeding migrations in tropical reef fishes. Helgoländer Meeres. 24: 361-370

Hobson, E. S., Chess, J. R. (1978). Trophic relationships among fishes and plankton in the lagoon at Enewetak Atoll, Marshall islands. Fish. Bull. U.S. 76: 133-153

Hobson, E. S., Chess, J. R. (1986). Diel movements of resident and transient zooplankters above lagoon reefs at Enewetak Atoll, Marshall islands. Pacif. Sci. 40:7-25

Igushi, K., Mizuno, N. (1990). Diel changes of larval drift among amphidromous gobies in Japan, especially Rhinogobius brunneus. J. Fish Biol. 37: 255-264

Jansen, P. C. (1986). Laboratory observations of the kinematics in the aerated region of breaking waves. Coast. Eng. 9: 453-477

Johannes, R. E. (1981). Words of the lagoon (fishing and marine lore in the Palau district of Micronesia). University of California Press, San Francisco

Jones, G. P. (1990). The importance of recruitment to the dynamics of a coral reef fish population. Ecology 71 : $1691-1698$

Kingsford, M. J., Choat, J. M. (1989). Horizontal distribution patterns of presettlement reef fish: are they influenced by the proximity of reefs? Mar. Biol. 101: 285-297

Kobayashi, D. R. (1989). Fine-scale distribution of larval fishes: patterns and processes adjacent to coral reefs in Kaneohe Bay, Hawaii. Mar. Biol. 100: 285-294

Leis, J. M. (1986). Vertical and horizontal distribution of fish larvae near coral reefs at Lizard Island, Great Barrier Reef Mar. Biol. 90: 505-516

Leis, J. M. (1991a). The pelagic stage of reef fishes: the larval biology of coral reef fishes. In: Sale, P. F. (ed.) The ecology of fishes on coral reefs. Academic Press, San Diego, p. $183-230$

Leis, J. M. (1991b). Vertical distribution of fish larvae in the Great Barrier Reef Lagoon, Australia. Mar. Biol. 109: $157-166$

Leis, J. M., Rennis, D. R. (1983). The larvae of Indo-Pacific coral reef fishes. New South Wales Univ. Press, Sydney 
Leis, J. M., Trnski, T (1989). The larvae in Indo-Pacific shorefishes. New South Wales University Press, Sydney

Leis, J. M., Trnski, T., Harmelin-Vivien, M., Renon, J-P., Dufour, V., El Moudni, K., Galzin, R. (1991). High concentrations of tuna larvae (Pisces: Scombridae) in near-reef waters of French Polynesia (Society and Tuamotu Islands). Bull. mar. Sci. 48: 150-158

Lenhardt, X. (1991). Hydrodynamique des lagons d'atoll et d'île haute en Polynésie française. Coll. études et theses, ORSTOM, Paris

Lough, R. G., Bolz, G. R. (1989). The movement of cod and haddock larvae onto the shoals of Georges bank. J. Fish. Biol. 35 (Suppl. A) : 71-79

McFarland, W. N., Ogden, J. C. (1985). Recruitment of young coral reef fishes from the plankton. In: Reaka, M. L. (ed.) The ecology of coral reefs. NOAA Symp. Ser. Undersea Res. 3: 37-51

Milicich, M. J. (1988). The distribution and abundance of presettlement fish in the nearshore waters of Lizard Island Proc. 6th int. coral Reef Symp. 2: 785-790

Neilson, J. D., Perry, R. I. (1990). Diel vertical migrations of marine fishes: an obligate or facultative process? Adv. mar. Biol. 26: 115-168

Randall, J. E. (1985). Fishes in: Fauna and Flora, a first compendium of French Polynesia sea-dwellers. Proc. 5th int coral Reef Cong. 1: 462-481

Randall, J. E., Brock, V. E. (1960). Observations on the ecology of epinepheline and lutjanid fishes of the Society Islands, with emphasis on food habits. Trans. Am. Fish. Soc. $89: 9-16$

Richards, W. J., Lindeman, K. C. (1987). Recruitment dynamics of reef fishes: planktonic processes, settlement and demersal ecologies, and fishery analysis. Bull. mar. Sci. 41: $392-410$

Robertson, D. R. (1992). Patterns of lunar settlement and early recruitment in Caribbean reef fishes at Panama. Mar. Biol. 114: $527-537$

Robertson, D. R., Green D. G., Victor, B. C. (1988). Temporal coupling of production and recruitment of larvae of a caribbean reef fish. Ecology 69: 370-381

Sale, P. F. (1969). Pertinent stimuli for habitat selection by the juvenile Manini Acanthurus triostegus sandvicensis. Ecology 50: 616-623

Sale, P. F., Doherty, P. J., Eckert, G. J., Douglas, W. A., Ferrel, D. J. (1984). Large scale spatial and temporal variation in

This article was submitted to the editor recruitment of fish populations on coral reefs. Oecologia 64: $191-198$

Shulman, M. J., Ogden, J. C. (1987). What controls tropical reef fish populations: recruitment or benthic mortality? An example in the Caribbean reef fish: Haemulon flavolineatum. Mar. Ecol. Prog. Ser. 39: 233-242

Sweatman, H. A. (1985). The timing of settlement by larvae Dascyllus aruanus: some consequences for larval habitat selection. Proc. 5th int. coral Reef Cong. 5: $367-371$

Thorrold, S. R. (1992). Evaluating the performance of light traps for sampling small fish and squid in open waters of the central Great Barrier Reef lagoon. Mar. Ecol. Prog. Ser. 89: $277-285$

Tranter, D. J., Bulleid, N. C., Campbell, R., Higgins, H. W., Rowe, F., Tranter, H. A., Smith, D. F. (1981). Nocturnal movements of phototactic zooplankton in shallow waters. Mar. Biol. 61: 317-326

Victor, B. C. (1983). Recruitment and population dynamics of a coral reef fish. Science 219:419-420

Victor, B. C. (1984). Coral reef fish larvae: patch size estimation and mixing in the plankton. Limnol. Oceanogr. 29: 1116-1119

Victor, B. C. (1986). Larval settlement and juvenile mortality in a recruitment-limited coral reef fishes population. Ecol. Monogr. 56: 145-160

Victor, B. C. (1991). Settlement strategies and biogeography of reef fishes. In: Sale, P. F. (ed.) The ecology of fishes on coral reefs. Academic Press, San Diego, p. 231-260

Webb, P. W. Weihs, D. (1986). Functional locomotor morphology of early life history stages of fishes. Trans. Am. Fish. Soc. 115: 115-127

Whitfield, A. K. (1989). Ichthyoplankton in a southern african surf zone: nursery area for the postlarvae of estuarine associated fish species? Estuar. coast. Shelf Sci. 29: $533-547$

Williams, D. McB. (1983). Daily, monthly and yearly variability in recruitment of a guild of coral reef fishes. Mar. Ecol. Prog. Ser. 10: 231-237

Williams, D. McB. (1986). Spatial and temporal scales of processes determining inter-annual variation in recruitment of fishes of the Great Barrier Reef: some preliminary data. In: IOC Workshop Rep. Ser., Suppl. 44. UNESCO, Paris, p. $229-239$

Manuscript first received: March 22, 1993

Revised version accepted: August 26, 1993 